\author{
Abstracta Iranica \\ Abstracta Iranica Revue bibliographique pour le domaine irano-aryen \\ Volume 37-38-39 | 2018 \\ Comptes rendus des publications de 2014-2016
}

\title{
Caroline Waerzeggers. « A Statue of Darius in the Temple of Sippar »
}

\section{Astrid Nunn}

\section{(2) OpenEdition}

\section{Journals}

Édition électronique

URL : http://journals.openedition.org/abstractairanica/42567

DOI : 10.4000/abstractairanica.42567

ISBN : 1961-960X

ISSN : 1961-960X

Éditeur :

CNRS (UMR 7528 Mondes iraniens et indiens), Éditions de l'IFRI

Référence électronique

Astrid Nunn, "Caroline Waerzeggers. "A Statue of Darius in the Temple of Sippar » », Abstracta Iranica [En ligne], Volume 37-38-39 | 2018, document 9, mis en ligne le 10 mars 2018, consulté le 28 septembre 2020. URL : http://journals.openedition.org/abstractairanica/42567 ; DOI : https://doi.org/ 10.4000/abstractairanica.42567

Ce document a été généré automatiquement le 28 septembre 2020

Tous droits réservés 


\title{
Caroline Waerzeggers. « A Statue of Darius in the Temple of Sippar »
}

\author{
Astrid Nunn
}

\section{RÉFÉRENCE}

Caroline Waerzeggers. " A Statue of Darius in the Temple of Sippar », in Michael Kozuh, Wouter F. M. Henkelman, Charles E. Jones, Christopher Woods (eds.). Extraction \& Control: Studies in Honor of Matthew W. Stolper. Studies in Ancient Oriental Civilization 68. Chicago, The Oriental Institute of the University of Chicago, 2014, p. 323-329.

1 Une tablette de Sippar décrit les offrandes d'avoine et de dattes que reçoit une statue du roi perse Darius I sous le règne de son successeur Xerxès dans l'Ebabbar de Sippar. Ce texte est le seul à évoquer le culte de statues de rois perses en Babylonie.

\section{AUTEURS}

ASTRID NUNN

Université de Munich 